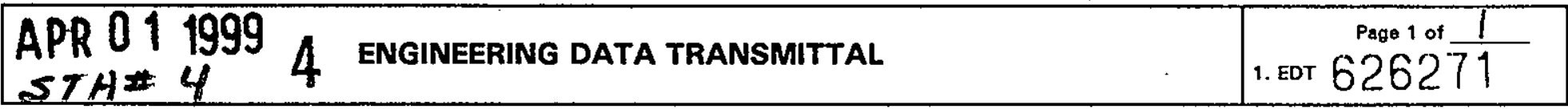

\begin{tabular}{|l|l|l|l|}
\hline $\begin{array}{l}\text { 2. To: (Receiving Organization) } \\
\text { Distribution }\end{array}$ & $\begin{array}{l}\text { 3. From: (Originating Organization) } \\
\text { SNF Project }\end{array}$ & $\begin{array}{l}\text { 4. Related EDT No.: } \\
\text { N/A }\end{array}$ \\
\hline 5. Proj./Prog./Dept/Div.: & $\begin{array}{l}\text { 6. Design Authority/ Design Agent/Cog. } \\
\text { Engr.: } \\
\text { C. Van Katwijk }\end{array}$ & \multicolumn{2}{|c|}{ 7. Purchase Order No.: } \\
Spent Nuclear Fuel Project
\end{tabular}

16.

KEY

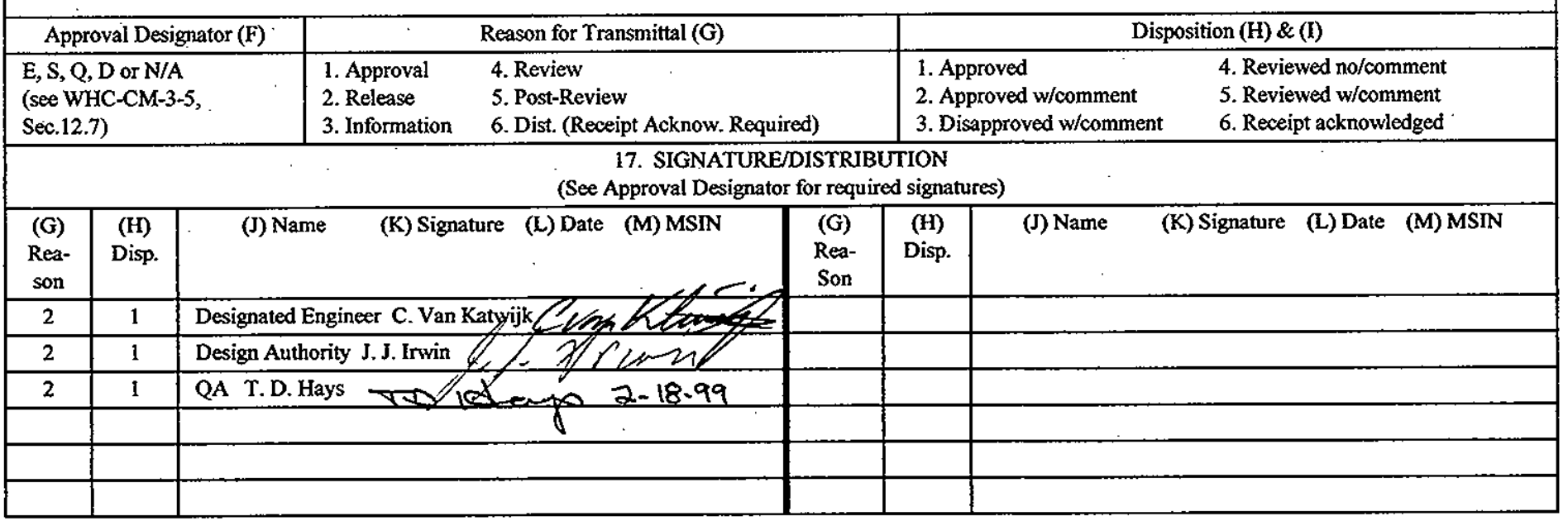

\begin{tabular}{|l|l|l|l|l|}
\hline 18. & 19. \\
$\begin{array}{l}\text { Signature of EDT } \\
\text { Originator. }\end{array}$
\end{tabular}




\section{Krohne Flow Indicator and High Flow Alarm - Local Indication and High Flow Alarm of Helium Flow from the SCHe Purge Lines C \& D to the Process Vent}

Carl Van Katwijk

Numatec Hanford Co, Richland, WA 99352

U.S. Department of Energy Contract DE-AC06-96RL13200

EDT/ECN: 626271

Org Code: $2 \mathrm{G} 300$

B\&R Code: $39 \mathrm{EW} 40400$
UC: 620

Charge Code: $105559 / \mathrm{A} 000$

Total Pages: 13

Key Words: Flow indicators - Alarms, process vents

Abstract: Krohne Flow Indicator and High flow Alarm - Local Indication and High Flow Alarm of Helium Flow from the SCHe Purge Lines C \& D to the Process Vent CGI-SNF-D-13-P5-025

TRADEMARK DISCLAIMER. Reference herein to any specific commercial product, process, or service by trade name, trademark, manufacturer, or otherwise, does not necessarily constitute or imply its endorsement, recommendation, or favoring by the United States Government or any agency thereof or its contractors or subcontractors.

Printed in the United States of America. To obtain copies of this document, contact: Document Control Services, P.O. Box 950, Mailstop H6-08, Richland WA 99352, Phone (509) 372-2420; Fax (509) 376-4989.

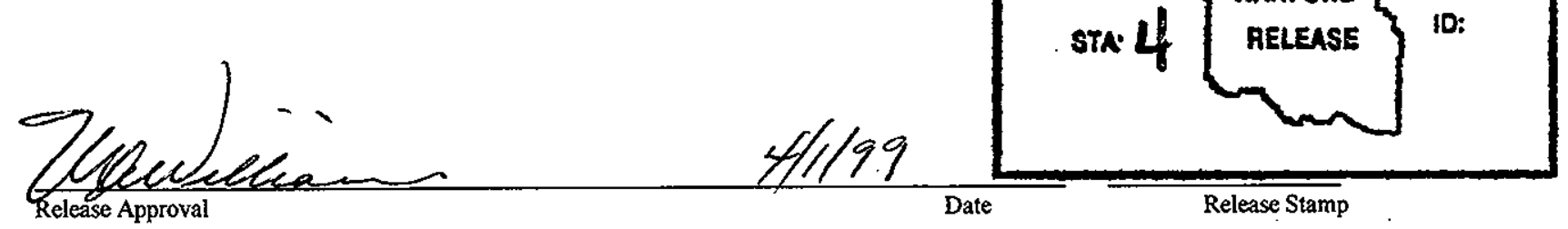


Commercial Grade Item Upgrade Dedication Form

ECNNo. NA CGINo. CGISNE-D-13-P5-025

Title: KROHNE FLOW INDICATOR AND HIGH FLOW ALARM-

LOCAL INDICATION AND GIGH FLOW ALARM OF HELIUM FLOW

FROM.THE SCHE PURGE LINES C \& D TO THE PROCESS VENT

\begin{tabular}{|c|c|c|c|}
\hline Item No.: NA & \multicolumn{2}{|l|}{ Manufacturer: } & Supplier: \\
\hline \multicolumn{2}{|l|}{ Mfg. Part/Model No.: } & \multicolumn{2}{|l|}{ Supplier's P/N: } \\
\hline \multicolumn{4}{|l|}{ Part Description: } \\
\hline \multicolumn{4}{|l|}{ End Use Description: } \\
\hline \multicolumn{4}{|c|}{ 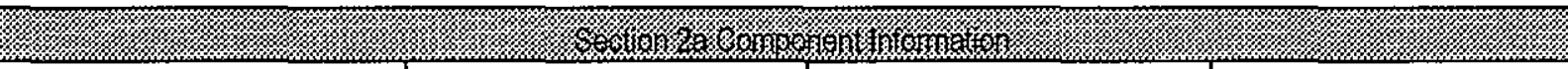 } \\
\hline $\begin{array}{l}\text { Equipment No.: PV- } \\
\text { Fl/FSH-5*52, }-5 * 72\end{array}$ & $\begin{array}{l}\text { Specification No.: W-441- } \\
\text { P5, Rev. } 2\end{array}$ & Manufacturer: Krohne & Past P.O. No.: NA \\
\hline $\begin{array}{l}\text { Manufacturer's Part/Model } \\
\text { No.: DK 37/MR K200 } \\
\text { W/120 VAC Relay W/O } \\
\text { Needle Valve }\end{array}$ & Equipment Supplier (if differe & from manufacturer): TB & $\begin{array}{l}\text { Equip. Supplier's Part No.: } \\
\text { NA }\end{array}$ \\
\hline
\end{tabular}

Component Description: Flow Indicators/alarms FI/FSH-5* 52 and $-5 * 72$ are located in the process vent lines connected to the $2 \mathrm{psig}$ SCHe purge lines $\mathrm{C}$ and $\mathrm{D}$. They monitor the flow from the $2 \mathrm{psig}$ SCHe purge going to the process vent. The switch/alarm is safety class GS.

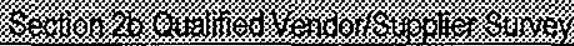

1. Is the Item available from a catalog from a qualified NQA1 Engineer or BTR)?

l J YES (go to \#2 below)

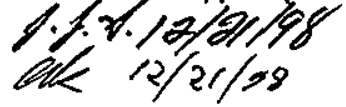

[X] NO (go to procedure step 5.3.2, proceed to dedicate item.)

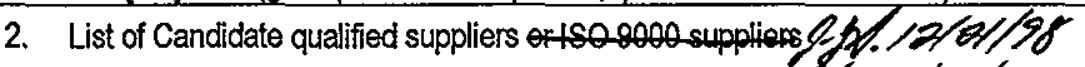
company name and type

contact name

NA

3. Recommended Procurement Strategy (coordinate with project CGl interface Engineer or BTR):

NA

\section{8.}

1. Question \#1: Is the Item subject to design or specification requirements that are unique to nuclear facilities or activities?

[ 1 YES (the ltem is not commercial grade)

[X] No (continue)

2. Question \#2: Is the Item used in applications other than nuclear facilities or activities?

[ 1 NO (the item is not commercial grade)

[X] YES (continue) 
Title: KROḦNE FLOW INDICATOR AND HIGH FLOW ALARM-

\section{LOCAL INDICATION AND HIGH FLOW ALARM OF BELIUM FLOW}

FROM THE SCHE PURGE LINES C \& D TO THE PROCESS VENT

3. Question \#3: Is the Item ordered from manufacturer/supplier on the basis or specifications set forth in the manufacturers catalog?

I ] NO (the ltem is not commercial grade)

[X] YES (continue)

[X] All three criteria have been satisfied. The Item meets the definition of commercial grade.

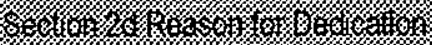

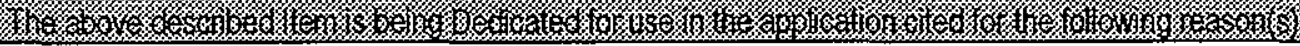

[X] Item is being purchased from a non ESL manufacturer supplier as commercial grade to be used in a Safety Class application.

[ ] Item is being purchased from a non ESL manufacturer supplier as commercial grade to be used in a Safety Significant application.

[ ] Item was purchased from a non ESL manufacturer supplier as commercial grade to be used in a Safety Class application.

[ ] Item was purchased from a non ESL manufacturer supplier as commercial grade to be used in a Safety Significant application.

1 other ('like-for-like', similar, substitution, replacement evaluation)

\section{A. Part/Component Safety Function:}

1. Pressure Boundary Integrity- Prevents helium leakage from the 2 psig SCHe System.

\section{Maintain pressure boundary after seismic event.}

3.

B. Par/Component Functional Mode

Safety Function \#1:

[ ] Active -Mechanical or Electrical change of state is required to occur for the component to perform its safety function

[X] Passive - Change of state is not required for the component to perform its safety function Safety Function \#2:

[ ] Active - Mechanical or Electrical change of state is required to occur for the component to perform its safety function.

[X] Passive - Change of state is not required for the component to perform its safety function Safety Function \#3:

I ] Active - Mechanical or Electrical change of state is required to occur for the component to perform its safety function.

[ ] Passive - Change of state is not required for the component to perform its safety function

C. Host Component Safety Function (if applicable):

1. NA

2.

3. 
Title: KROHNE FLOW INDICATOR AND HIGH FLOW ALARM LOCAL INDICATION AND HIGH FLOW ALARM OF HELIUM FLOW FROM THE SCHE PURGE LINES C \& D TO THE PROCESS VENT

D. Failure Mechanisms(s) and the effects on component or system safety function (see worksheet 1):

1. Fracture of the indicator body or of the piping connection - helium leakage from the 2 psig $\mathrm{SCHe}$ System.

$$
2 .
$$

3.

4.

5.

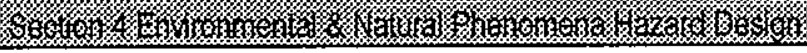

Environmental Qualification Required:

If yes: Environmental Qualification Requirements

Yes [ ]

No $[\mathbf{X}]$

Limiting Environmental Conditions:

Environmental Condition B

Required Safety Functions:

Qualification Period:

Natural Phenomena Hazard (NPH) Design Required:

Yes [X]

If yes: NPH Design Requirements

No [ ]

Performance Category: PC-3

NPH Design Req'ts.: Seismic Condition B

HNF-PRO-97, Rev. 0

Required Safety Functions: Pressure Boundary

W-441-P5, Rev. 2 Integrity.

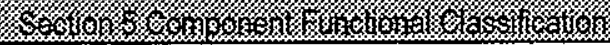

[X] Safety Class (SC)

I JGeneral Sevice

[ ] Safety Significant (SS)

If part/component classification is different from host component/system, document basis.

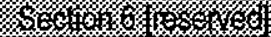

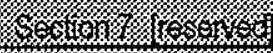

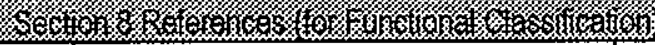

National Codes/Standards: IEEE 344,

Safety Analysis Report (SAR):

ISA-S5.1, -S5.4, -S18.1, -S20 HNF-SD-SNF-SAR-002,

Rev. 4A

Drawings: H-1-82165, Rev. 2

HNF-SD-SNF-SEL-002, Rev. 4 CVDF-SSD-003

Vendor Manuals/Manufacturer/Supplier Information: Krohne Product Survey - Variable Area Flowmeters Other. 
Title: KROHNE FLOW INDICATOR AND HIGH FLOW ALARM-

LOCAL INDICATION AND HIGH FLOW ALARM OF HELIUM FLOW

FROM THE SCHE PURGE LINES C \& D TO THE PROCESS VENT

\begin{tabular}{|c|c|c|c|c|}
\hline \begin{tabular}{l}
\multicolumn{1}{c}{ Critical Characteristics } \\
Verification Document: Vendor \\
Specifications, \\
HNF-SD-SNF-SEL-002, Rev. 4
\end{tabular} & Acceptance Criteria/Tolerances & $\begin{array}{l}\text { Acceptance } \\
\text { Method }\end{array}$ & ID & Function \\
\hline \multicolumn{5}{|c|}{ 1. Item Identification Critical Characteristics (necessary for reasonable assurance that the ltem deljvered is the Item specified) } \\
\hline Namepiate Data & Per Vendor Manual & $1, \mathbb{I N}$ & $\mathbf{x}$ & \\
\hline Model Number & $\begin{array}{l}\text { DK 37/MR K200 W/120 VAC } \\
\text { Relay W/O Needle Valve }\end{array}$ & $1, \mathrm{ln}$ & $\mathbf{X}$ & \\
\hline Manufacturer & Krohne & 1,IN & $\mathbf{X}$ & \\
\hline Process Connection & $\begin{array}{l}1 / 4 \text { Inch FNPT (Horizontal } \\
\text { Connections) }\end{array}$ & $1, \mathrm{IN}$ & $\mathbf{X}$ & \\
\hline Indicator Range & $0.34-3.4$ SCFM & $1, \mathrm{IN}$ & $\mathbf{x}$ & \\
\hline \multicolumn{5}{|c|}{ 2. Physical Critical Characteristics (necessary for reasonable assurance that the Item delivered is the Item specified) } \\
\hline Material, Body & Stainless Steel & $1, T$ & $\mathbf{x}$ & \\
\hline Material, Process Connection & Stainless Steel & $1, T$ & $\underline{\mathbf{X}}$ & \\
\hline \multicolumn{5}{|c|}{$\begin{array}{l}\text { 3. Performance Critical Characteristics (necessary \& sufficient for reasonable assurance that the ltem will perform its intended } \\
\text { safety function(s)) }\end{array}$} \\
\hline Pressure Boundary Integrity & $\begin{array}{l}\text { No Leakage at Test Pressure of } \\
165 \text { Psig. Note } 3 \text {. }\end{array}$ & $1, \mathrm{~T}$ & & $\mathbf{x}$ \\
\hline Environmental & Note 1 & & & \\
\hline Seismic Condition B & Note 2 & $1, T$ & & $\mathbf{X}$ \\
\hline \multicolumn{2}{|c|}{$\begin{array}{l}\text { 4. Notes and Legend: } \\
\text { 1. The flow indicator is not subject to degradation at ambient } \\
\text { conditions of } 40^{\circ} \mathrm{F} \text { and } 60 \% \mathrm{RH} \text { or } 115^{\circ} \mathrm{F} \text { and } 22 \% \mathrm{RH} \text { and } \\
\text { is suitable for Environmental. Condition } \mathrm{B} \text { application. } \\
\text { 2. Maintain pressure boundary after Seismic event. } \\
\text { W-441-P5, Rev. } 2 \text {, Appendix I, page } 1-2 \text {, provides a seismic } \\
\text { testing plan for these components at a seismic spectra } \\
\text { TBD. } \\
\text { 3. Pressure test at } 110 \% \text { of system design pressure of } 150 \\
\text { psig. Exposure to test pressure may seriously degrade } \\
\text { the readout function. This test is considered to be a } \\
\text { destructive test. }\end{array}$} & \multicolumn{3}{|c|}{$\begin{array}{l}\text { Acceptance Method: } \\
\text { 1. Special Test and Inspection } \\
\text { 1,IN for Inspection } \\
1, T \text { for Test } \\
\text { 2. Commercial Grade Survey } \\
\text { 3. Source Verification } \\
\text { 4. Vendor/ltem History }\end{array}$} \\
\hline
\end{tabular}




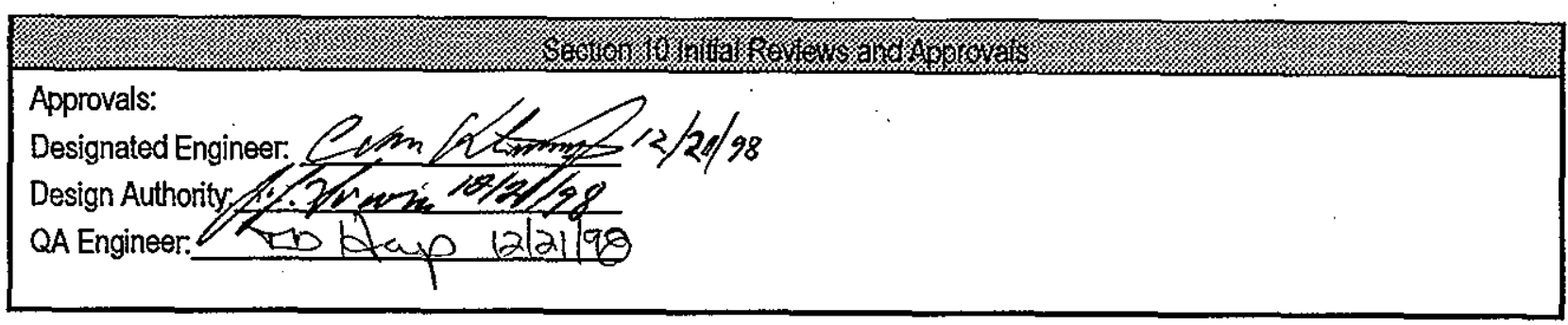


Commercial Grade Item Upgrade Dedication Form

ECN No. NA CGINo. CGI-SNF-D-13-P5-025

Title: KROHNE FLOW INDICATOR AND HIGH FLOW ALARM-

LOCAL INDICATION AND FIGH FLOW ALARM OF FELIUM FLOW

FROM THE SCHE PURGE LINES C \& D TO THE PROCESS VENT

\begin{tabular}{|c|c|c|}
\hline \multicolumn{3}{|c|}{$\begin{array}{c}\text { WORKSHEET } 1 \\
\text { DETERMINATION OF FAILURE MECHANISMSMODES }\end{array}$} \\
\hline \multicolumn{3}{|c|}{ স্য় } \\
\hline $\begin{array}{l}\text { Typical Failure } \\
\text { Mechanisms }\end{array}$ & Definition & $\begin{array}{l}\text { Applicable to Component } \\
\text { under Evaluation }\end{array}$ \\
\hline \multirow[t]{3}{*}{ Fracture } & $\begin{array}{l}\text { Separation of a solid accompanied by little or no } \\
\text { macroscopic plastic deformation. }\end{array}$ & $\begin{array}{l}\text { Yes [X ] No [ ]; lf Yes, indicate } \\
\text { failure Mode. Failure of }\end{array}$ \\
\hline & & Transmitter Body or the \\
\hline & \multirow{4}{*}{$\begin{array}{l}\text { The gradual deterioration of a material due to } \\
\text { chemical or electrochemical reactions, such as } \\
\text { oxidation, between the material and its environment. } \\
\text { Destruction of materials by the abrasive action of } \\
\text { moving fluids, usually accelerated by the presence } \\
\text { of solid particles carried with the fluid. } \\
\text { An electrical circuit that is unintentionally broken so } \\
\text { that there is no complete path for current flow. }\end{array}$} & Process Connection \\
\hline Cortosion & & $\begin{array}{l}\text { Yes [ ] No [X]; If Yes, indicate } \\
\text { failure Mode. }\end{array}$ \\
\hline Erosion & & $\begin{array}{l}\text { Yes [ ] No [X]; if Yes, indicate } \\
\text { failure Mode. }\end{array}$ \\
\hline Open Circuit & & $\begin{array}{l}\text { Yes [ ] No [X]; If Yes, indicate } \\
\text { failure Mode. }\end{array}$ \\
\hline Short Circuit & \multirow{3}{*}{$\begin{array}{l}\text { An abnormal connection by which an electrical } \\
\text { current is connected to ground, or to some } \\
\text { conducting body, resulting in excessive current flow. } \\
\text { Clogging of a filtering medium resulting in the } \\
\text { inability to perform its purification function or } \\
\text { blockage of flow. } \\
\text { Binding of a normally moving item through excessive } \\
\text { pressure, temperature, friction, jamming. }\end{array}$} & $\begin{array}{l}\text { Yes [ ] No [X]; if Yes, indicate } \\
\text { failure Mode. }\end{array}$ \\
\hline Blockage & & $\begin{array}{l}\text { Yes [] No [X]; If Yes, indicate } \\
\text { failure Mode. }\end{array}$ \\
\hline Seizure & & $\begin{array}{l}\text { Yes [] No [X]; if Yes, indicate } \\
\text { failure Mode. }\end{array}$ \\
\hline Unacceptable Vibration & \multirow{2}{*}{$\begin{array}{l}\text { Mechanical oscillations produced are beyond the } \\
\text { defined pemissible limits due to unbalancing, poor } \\
\text { support, or rotation at critical speeds. } \\
\text { A loss of mechanical and physical properties of a } \\
\text { material due to exposure to high temperatures, } \\
\text { radiation exposure. }\end{array}$} & $\begin{array}{l}\text { Yes [ ] No [X]; If Yes, indicate } \\
\text { failure Mode. }\end{array}$ \\
\hline Loss of Properties & & $\begin{array}{l}\text { Yes [ ] No [X]; If Yes, indicate } \\
\text { failure Mode. }\end{array}$ \\
\hline Excess Strain & $\begin{array}{l}\text { Under the action of excessive external forces the } \\
\text { material of the part has been deformed or distorted. }\end{array}$ & $\begin{array}{l}\text { Yes [ ] No [X]; If Yes, indicate } \\
\text { failure Mode. }\end{array}$ \\
\hline Mechanical Creep & \multirow{2}{*}{$\begin{array}{l}\text { From prolonged exposure to high temperature and } \\
\text { stress, the object will show a slow change in its } \\
\text { physical (shape and dimension) and mechanical } \\
\text { characteristics. } \\
\text { Fracture characterized by tearing of metal } \\
\text { accompanied by appreciable gross plastic } \\
\text { deformation. }\end{array}$} & $\begin{array}{l}\text { Yes [ ] No [X]; If Yes, indicate } \\
\text { failure Mode. }\end{array}$ \\
\hline Ductile Fracture & & $\begin{array}{l}\text { Yes [ ] No [X]; If Yes, indicate } \\
\text { failure Mode. }\end{array}$ \\
\hline \multicolumn{3}{|c|}{ 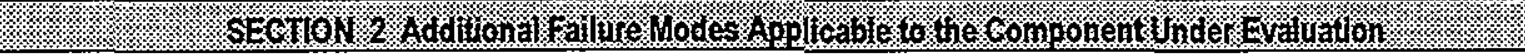 } \\
\hline Process Conn & /Body Break & \\
\hline
\end{tabular}




\section{CHECKLIST 1}

ACCEPTANCE METHOD 1

SPECIAL TEST/INSPECTION VERUTCATION

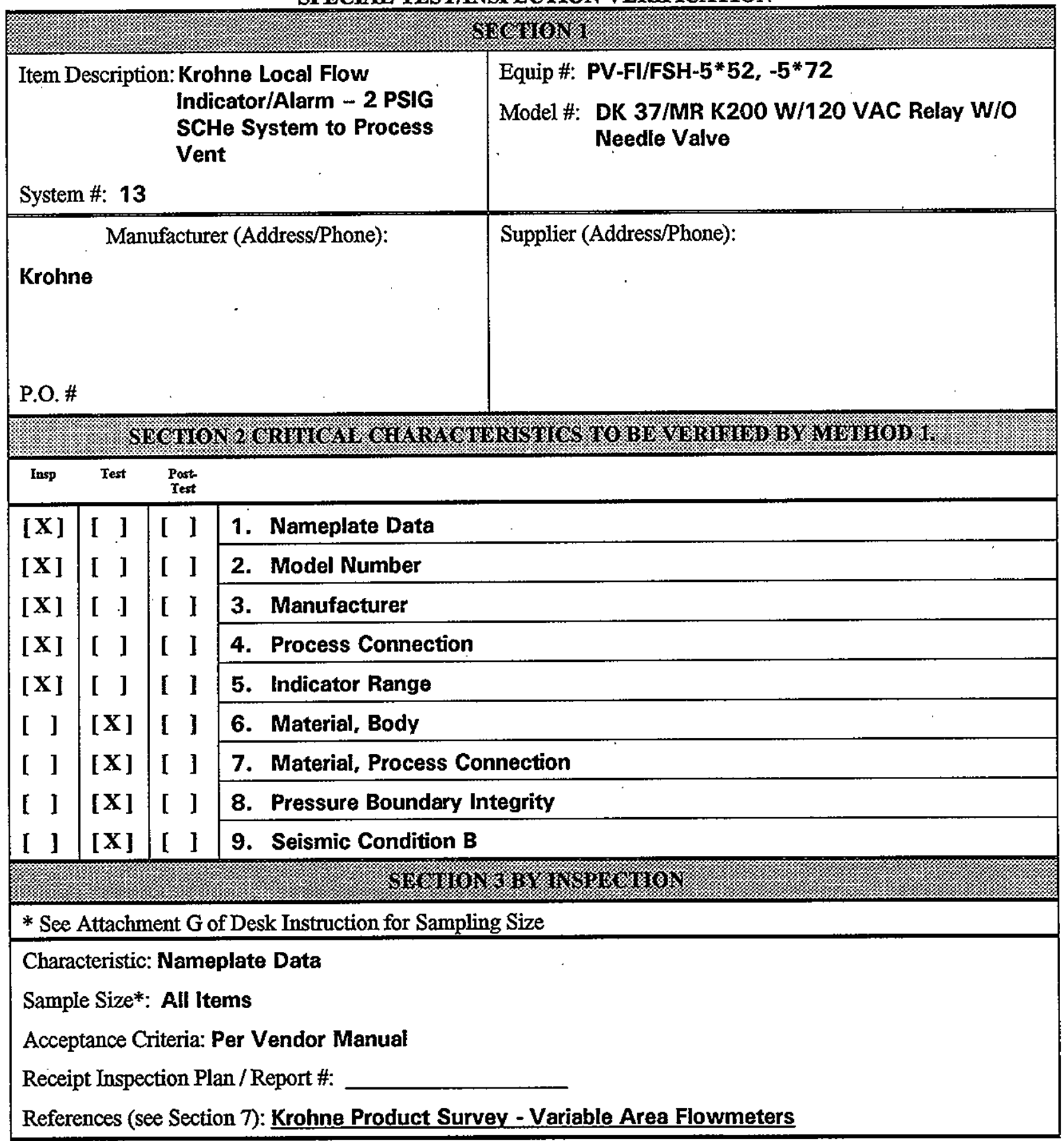


Title: KROBNE FLOW INDICATOR AND HIGH FLOW ALARM-

LOCAL INDICATION AND HIGH FLOW ALARM OF HELIUM FLOW

FROM THE SCHE PURGE LINES C \& D TO THE PROCESS VENT

Characteristic: Model Number

Sample Size*: All Items

Acceptance Criteria: DK 37/MR K200 W/120 VAC Relay W/O Needle Valve

Receipt Inspection Plan / Report \#:

References (see Section 7):

Characteristic: Manufacturer

Sample Size*: All ltems

Acceptance Criteria: Krohne

Receipt Inspection Plan / Report \#:

References (see Section 7):

Characteristic: Process Connection

Sample Size*: All Items

Acceptance Criteria: 1/4 Inch FNPT (Horizontal Connections)

Receipt Inspection Plan / Report \#:

References (see Section 7):

Characteristic: Indicator Range

Sample Size*: All Items

Acceptance Criteria: 0.34 - 3.4 SCFM

Receipt Inspection Plan / Report \#:

References (see Section 7):

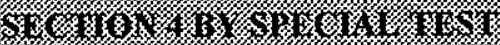

* See Attachment G of Desk Instruction for Sampling Size

Test To Be Performed by:

Number of Items to be Tested:

[ ] Purchaser

[ ] Supplier/Manufacturer**

Test/Inspection Location:

[ ] Other

Characteristic for Test: Material, Body

Acceptance Criteria: Stainless Steel

Sample Size*: Normal Sampling Size

Actual Test Value:

Test Plan and Report \#: References (see Section 7): 
Title: KROHNE FLOW INDICATOR AND HIGH FLOW ALARM-

LOCAL INDICATION AND HIGH FLOW ALARM OF HELIUM FLOW

FROM THE SCHE PURGE LINES C \& $D$ TO THE PROCESS VENT

Characteristic for Test: Material, Process Connection

Acceptance Criteria: Stainless Steel

Sample Size*: Normal Sampling Size

Actual Test Value:

Test Plan and Report \#: References (see Section 7):

Characteristic for Test: Pressure Boundary Integrity

Acceptance Criteria: No Leakage at Test Pressure of 165 Psig

Sample Size*: Destructively Test Only One Item

Actual Test Value:

Test Plan and Report \#: References (see Section 7):

Characteristic for Test: Seismic Condition B

Acceptance Criteria: Maintain Pressure Boundary After Seismic Event. W-441-P5, Rev. 2, Appendix I, page 1-2, provides a seismic testing plan for these components at a seismic spectra TBD.

Sample Size*: Normal Sampling Size

Actual Test Value:

Test Plan and Report \#: References (see Section 7):

**If Supplier/Manufacturer or Other, Refer to CGI Checklist-2 for Support Information 
Commercial Grade Item Upgrade Dedication Form

ECN No. NA CGINo. CGI-SNF-D-13-P5-025

Rev. No. 0 SNF. 3922

Title: KROHNE FLOW INDICATOR AND HIGH FLOW ALARM -

LOCAL INDICATION AND HIGH FLOW ALARM OF HELIUM FLOW

FROM THE SCHE PURGE LINES C \& D TO THE PROCESS VENT

\begin{tabular}{|c|c|c|c|c|c|c|c|c|c|c|c|}
\hline \multicolumn{12}{|l|}{ " " } \\
\hline \multicolumn{12}{|c|}{ 1. SUMMARY OF VERIFIED CRITICAL CHARACTERISTICS, THEIR VERIFICATION METHODS, AND RESULTS } \\
\hline \multicolumn{12}{|c|}{ ITEM DESCRIPTION: } \\
\hline \multicolumn{4}{|c|}{ Critical Characteristics } & \multicolumn{8}{|c|}{ Verification Results } \\
\hline Critical Characteristics & Acceptance CriteriaTolerances & $\mathbf{D}$ & Function & $\begin{array}{c}\text { Method } \\
\text { T/N }\end{array}$ & $\begin{array}{l}\text { Procedure } \\
\text { or RR\# }\end{array}$ & $\begin{array}{l}\text { Check- } \\
\text { list } \mathbb{D}\end{array}$ & $\begin{array}{l}\text { Number } \\
\text { Tested }\end{array}$ & $\begin{array}{c}\text { Number } \\
\text { Failed }\end{array}$ & $\begin{array}{c}\text { Verifying } \\
\text { Organization }\end{array}$ & Printed Name Signature & Date \\
\hline Nameplate Data & Per Vendor Manual & $\mathbf{X}$ & & & & & & & & & \\
\hline Model Number & $\begin{array}{l}\text { DK } 37 / M R \text { K } 200 \text { W/120 } \\
\text { VAC Relay W/O Needle } \\
\text { Valve }\end{array}$ & $\mathbf{x}$ & & - & & & & & & . & \\
\hline Manufacturer & Krohne & $\mathbf{X}$ & & & $\therefore$ & & & & & & \\
\hline Process Connection & $\begin{array}{l}1 / 4 \text { Inch FNPT } \\
\text { (Horizontal Connections) }\end{array}$ & $\mathbf{x}$ & & & & & & & & . & \\
\hline Indicator Range & $0.34-3.4$ SCFM & $\mathbf{x}$ & & & & & & & & & \\
\hline Material, Body & Stainless Steel & & $\mathbf{X}$ & & & & & & & & \\
\hline $\begin{array}{l}\text { Material, Process } \\
\text { Connection }\end{array}$ & Stainless Steel & & $\mathbf{x}$ & & & & & & & & \\
\hline $\begin{array}{l}\text { Pressure Boundary } \\
\text { Integrity }\end{array}$ & $\begin{array}{l}\text { No Leakage at Test } \\
\text { Pressure of } 165 \text { Psig }\end{array}$ & & $\mathbf{x}$ & & & & & & & & \\
\hline Environmental & NA & & & & & & & & & & \\
\hline Seismic Condition B & $\begin{array}{l}\text { Maintain Pressure } \\
\text { Boundary After Seismic } \\
\text { Event }\end{array}$ & & $\mathbf{x}$ & & & & & & & & \\
\hline
\end{tabular}


Commercial Grade Item Upgrade Dedication Form

ECN No. NA CGI No. CGI-SNF-D-13-P5-025

Rev. No. 0 SNF 3922

Title: KROHNE FLOW INDICATOR AND HIGH FLOW ALARM -

LOCAL INDICATION AND HIGH FLOW ALARM OF HELIUM FLOW

FROM THE SCHE PURGE LINES C \& D TO TAE PROCESS VENT

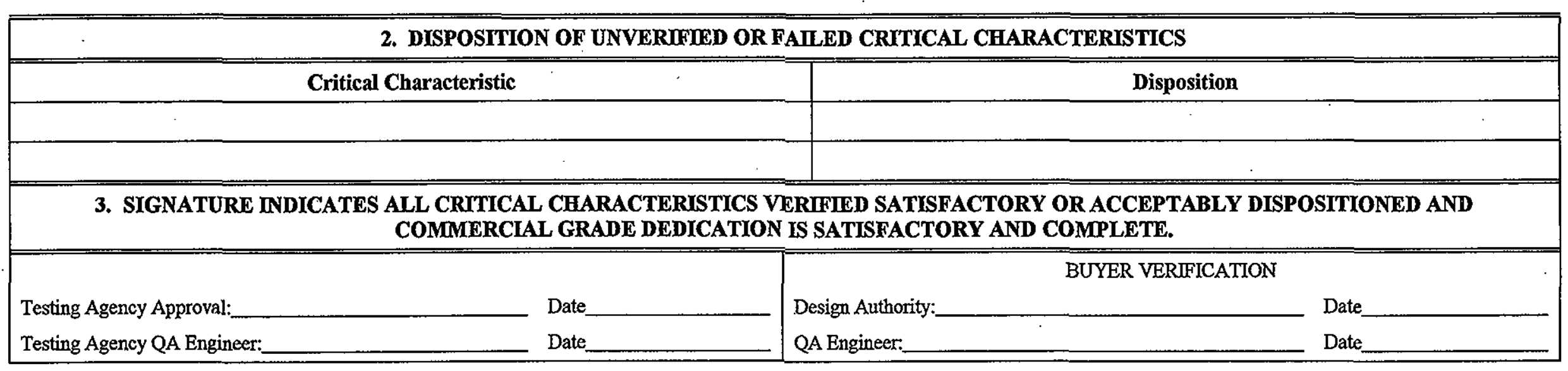


Commercial Grade Item Upgrade Dedication Form

ECN No. NA CGINo. CGI-SNF-D-13-P5-025

Title: KRROHNE FLOW INDICATOR AND HIGH FLOW ALARM -

LOCAL INDICATION AND HIGH FLOW ALARM OF HELIUM FLOW

FROM THE SCHE PURGE LINES C \& D TO THE PROCESS VENT

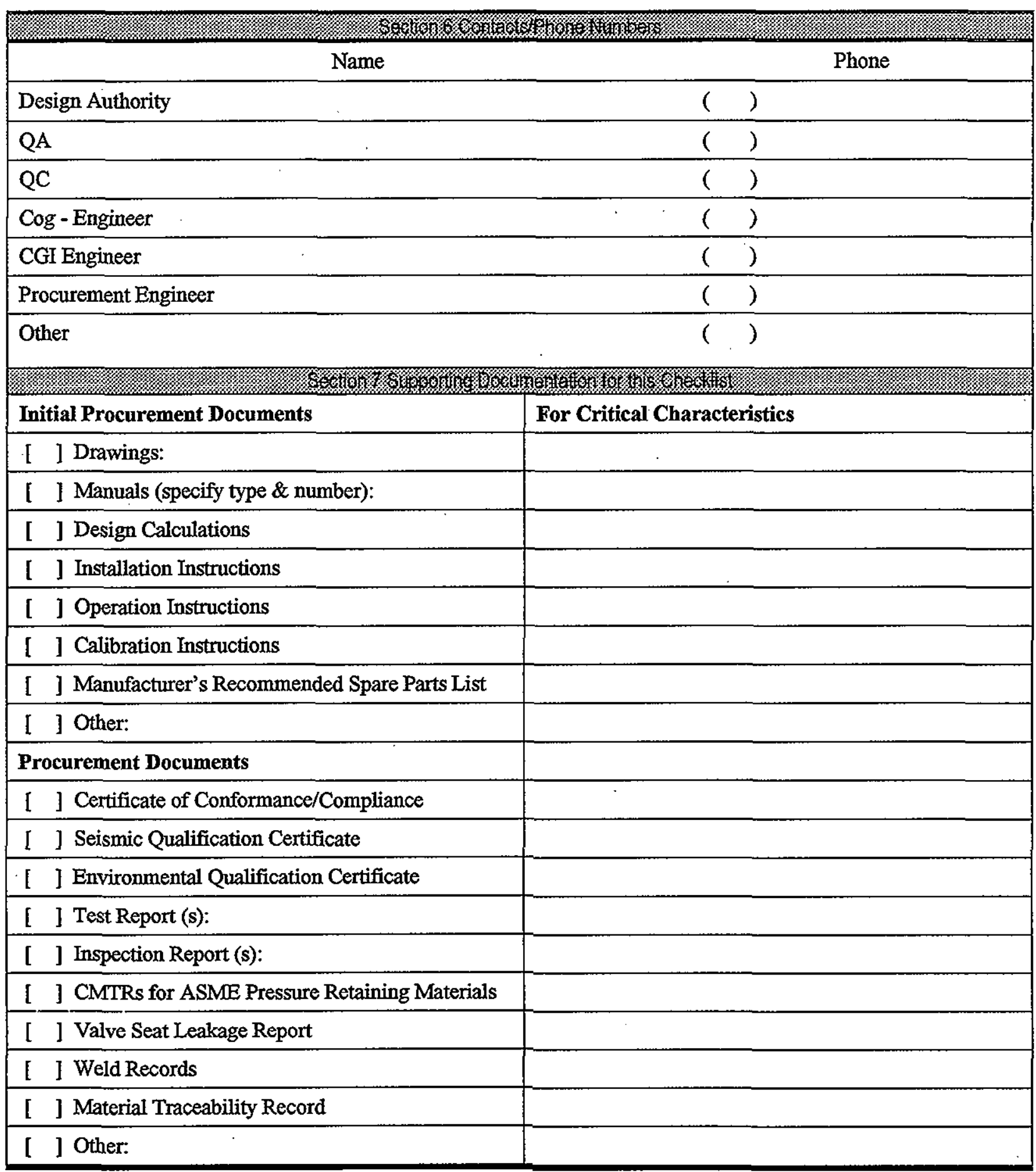

